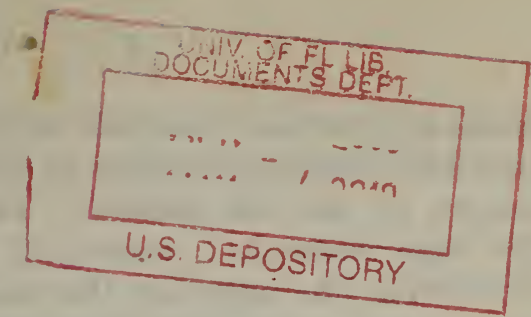

Issued March 2, 1912.

U. S. DEPARTMENT OF AGRICULTURE, BUREAU OF ANIMAL INDUSTRY.-CIRCULAR 198.

A. D. Melvin, Chief of Bureat.

\title{
THE BACTERIUM OF CONTAGIOUS ABORTION OF CATTLE DEMONSTRATED TO OCCUR IN MILK.
}

Investigations in the Bureau of Animal Industry have demonstrated the identity of a bacterium discovered in the milk of cows and the organism now widely recognized as the etiological factor in contagious abortion of cattle.

On August 24, 1911, in a paper presented at the annual meeting of the American Veterinary Medical Association by Drs. E. C. Schroeder and W. E. Cotton, of the Experiment Station of the bureau, under the title "An Undescribed Pathogenic Bacterium in Milk," attention was called to a peculiar pathological condition frequently found in guinea pigs that were injected with milk and afterwards permitted to live six weeks or longer. ${ }^{1}$

The microorganism to which the pathological condition in the guinea pigs was due was isolated, and it was definitely proven that it, and it alone, was the cause of the lesions, which, in their gross anatomical appearance, resembled the lesions of tuberculosis in guinea pigs so much that a distinction between the two pathological conditions was not certainly possible without microscopic examination. The microorganism was studied as carefully as the facilities for bacteriological work at the Experiment Station permitted.

As a matter of course the discovery of the peculiar microorganism, a small bacterium, aroused considerable interest in the bureau, and it was not long before Dr. John R. Mohler, Chief of the Pathological Division, called attention to the close resemblance of the organism found in milk to the bacterium of contagious abortion, in which latter he was interested because he was making investigations concerning contagious abortion of cattle.

1 See Proceedings of the American Veterinary Medical Association, 1911, pp. 4t2-149. Also Ameri. can Veterinary Reriew, Nov. 11, 1911, pp. 195-206.

$31535^{\circ}-12$ 
Experiments were at once undertaken, by Mohler on one hand and by Schroeder and Cotton on the other, to settle definitely the question of the identity of the two bacteria. The experiments have just reached the stage where it is absolutely certain that the bacillus isolated from milk-the organism that causes a slowly progressive disease in guinea pigs with lesions macroscopically like those of tuberculosis-is identical with the bacillus of contagious abortion of cattle.

Those who are familiar with the descriptions that have been given of the organism of contagious abortion of cattle-will easily recall how contradictory they are in many respects. Whether or not this is due to differences in the technique used by different investigators can not be said, but it is interesting to refer to the matter here, because the identity of the bacillus in milk and the organism of contagious abortion of cattle studied by Mohler would have been decided much earlier if one difficulty, now settled, had not stood in the way, namely, that the tests made at the Experiment Station at first showed the bacillus from milk to be a Gram positive organism while the other bacillus was found by the Fathological Division to be Gram negative. The bacillus, whether obtained from milk or from other sources, is now looked upon as being Gram negative.

The final test to establish the identity of the bacilli was the similarity obtained, by Mohler and Traum in the Pathological Division and by Schroeder and Cotton at the Experiment Station, working independently, in the lesions produced in guinea pigs inoculated respectively with the milk bacillus and the bacillus of contagious abortion, as well as the identity of the two organisms shown through the agency of the complement-fixation test.

In what respect the discovery of the bacillus of contagious abortion of cattle in the milk of cows is important can readily be seen by reading the paper presented by Schroeder and Cotton to the American Veterinary Medical Association, mentioned above. In that paper it is pointed out that it is questionable what may be the practical importance of this bacillus, now demonstrated to be the bacillus of contagious abortion, occurring: with a high degree of frequency in market milk. The fact that this organism was found in 8 samples of market milk among 77 samples tested (over 11 per cent), and in the milk distributed by 6 among 31 dairies (over 19 per cent), leaves no doubt that we are dealing with a phenomenon that is ominously serious in its significance for public health.

We do know that the organism causes abortion in cattle and some other nnimals, and that it causes progressive lesions of a serious character in some experiment animals; and although we do not know what effect it may have on human beings, we can not afford to assume that they are not affected by it. In this sense the bacillus forms another link in 
the long chain of facts that point unmistakably to the proper pasteurization of all milk before it is used as food as a measure essentially necessary for the protection of public health. ${ }^{1}$

A. D. Melvin, Chief of Bureau.

Approved:

JAMES WILsON,

Secretary of Agriculture.

Washington, D. C., February 27, 1912.

${ }^{1}$ Since this note was written, an article in the Centralblatt für Bakteriologie, Parasitenkunde und Infektionskrankheiten, vol. 61, No. 7, by Theobald Smith and Marshall Fabyan, has come to notice, in which attention is called to the probable occurrence of the bacillus of infectious abortion of cows in milk, to the disease it causes in guinea pigs, and to the possibility that it may cause disease in persons. 
